http://www.jfas.info

\title{
MATHEMATICAL MODELLING OF A FARM ENTERPRISE VALUE ON THE AGRICULTURAL MARKET WITH THE METHOD OF RESTRUCTURING ORDERED SETS
}

\author{
A.V. Molchanov*, V.P. Korsunov, E.V. Berdnova \\ Saratov State Agrarian University named after N.I. Vavilov, Teatralnaya 1, Saratov
}

Published online: 15 February 2017

\begin{abstract}
There is a set of farm enterprise elements to be assessed in terms of the effectiveness of their functioning, and there is a set of criteria for assessment of this effectiveness. An algorithm is needed that connects the elements and criteria, and allows determining the optimal variant of this system functioning for building of a mathematical model of the farm enterprise value on the agricultural market. Building of such model is possible with the model of ordered sets restructuring. The relevance of the problem is stipulated by the need to raise Russian farms to the level of peasant farms in the advanced countries. In 24 of the world's most developed countries, farms enjoy significant financial support from the state, reaching up to $40 \%$ of their total income [1]. Subsidies in the EU countries reached $45-50 \%$ of the value of commodity output produced by farmers, in Japan and Finland - 70, in Russia - only 3.5\% [2]. This financing gap entailed a number of negative consequences. Over the past 20 years, the rural population has decreased very significantly (by 50-70\%) in many areas of the Non-chernozem belt and in some areas of the Chernozem belt in the European part of Russia [3]. Commodity production also decreased. In order to eliminate negative trends, the country's authorities began to practice subsidies. In 2013, the Russian government began providing subsidies in the form of grants in the amount of 1.5 million rubles (and a one-off payment for arrangement 250 thousand rubles), and in 2017 raised the bar to 3,439 thousand rubles [4]. Subsidization is a positive factor, but it is necessary that it be optimal, that is, create the greatest effect in the development of peasant farms.
\end{abstract}

Author Correspondence, e-mail: author@gmail.com

doi: http://dx.doi.org/10.4314/jfas.v9i1s.740 
The purpose of the article is to create an objective criterion for determining the perspective direction in farms formation. The current practice of allocating investments to farms is subjective (by decision of the entities that are members of the relevant commissions). The objective criterion should not depend on the entities. The leading approach to the study of this problem is the development of an economic-mathematical model of such a criterion that completely excludes a subjective approach to such problems.

The main result of the article is the development of an economic-mathematical algorithm for determining the most efficient farm enterprise by the method of restructuring ordered sets.

The materials of the article can be useful to students of agricultural universities, farm managers and workers occupied in the agrarian sphere, connected with the formation of highly profitable farms.

Keywords: farm enterprise, value, mathematical model, method of restructuring.

\section{INTRODUCTION}

The socio-economic aspects of agrarian sphere are paid significant attention [5,6].

The world farming development history shows that farmers' movement originated in the USA, Canada, Australia and New Zealand as a consequence of virgin lands cultivation by European colonists. North American farmers' success factors were the following: favourable climate, convenient access to the sea through the Great Lakes for production export, stimulation of high prices in the domestic market by the government, subsidization and organizational and political support for food exports, direct subsidies and subventions, favourable social environment, long-term natural selection for vocational fitness, protestant (labour) morality and ethics dominance, capacious domestic market [7]. Unfortunately, there are no such factors in Russia.

In Western Europe, farming appeared in the conditions of the general capitalism development and landlord economy evolution. Private land ownership and land lease on favourable terms predetermined the creation of farms in Western countries [8]. At the initial stages, Russian farming was developing in the similar way.

As for farming development in the CIS countries (the former republics of the USSR), it, like in Russia, was legalized after 1990. The Farming Act of the Republic of Belarus was adopted $18^{\text {th }}$ February 1991 [9] (today it operates in the wording of 2005). The Ukrainian Farming Act came into force 19th June 2003 [10]. The legal regulation of farming development in the Republic of Kazakhstan is based on "Farming" Act of 31st March 1998 (formerly Peasant Farming Act of 21st May 1990) [11]. Of interest is farms functioning legal regulation 
development in the Republic of Uzbekistan. The first Farm Act was adopted $3^{\text {rd }}$ July 1992 [12]. For all its diversity, farming in CIS is the most similar to the Russian one.

The information given above suggests that the development of farming in Russia is at an early stage, and considerable efforts are required to bring it up to the advanced countries' level.

It is necessary to adopt the best foreign practices. However, there are many questions that require additional research.

Sufficient attention is paid to socio-economic aspects of the agrarian sector $[1,2]$. Nevertheless, there are a lot of issues requiring additional researches.

In autumn 2015, 200 representatives of large agricultural farms of Saratov region visited Germany for sharing of the experience. Part of them was representatives of those 286 farm enterprises which are engaged in the cattle breeding. But as early as in the winter advertisements for selling a number of MFE (mixed farm enterprises) appeared on the regional AGROSERVER site. It was connected with the policy, carried out in the area, of consolidation of farm enterprises, equipping them with advanced technology, rejuvenation of the staff and leading out them at the forefront in the global competition. Sale announcements are the consequence of this policy. At the same time, development of a technique for improving this policy is needed.

The reason for MFE sales is their poor effectiveness, and solution to the problem of livestock long-term development in the region is focused on the support (grants) of the most effective MFE from available. Due to this fact, the key issue is the objective determination of MFE effectiveness.

Until now the determination of MFE effectiveness was carried out at the expert level. Disadvantages of this level are known. The preferred method is the method of mathematical modelling. It excludes a personal influence. In the financial sector they pay attention to this. Black-Scholes formula is known for the assessment of real options. NPV formula - for calculation of cash flows in predicting the feasibility of investments. Other formulas are known for assessment of the value of commodities and companies [3]. But all of them concern financial institutions. MFE are not related to them. For such organizations there are no such formulas. There should be another approach for their calculation. Various methods for the total numerical estimation of the quality of goods are proposed [4]. But they also do not meet requirements under consideration. The application of the theory of ordered sets to vector spaces is known [5]. But it turns to be impossible to correlate a variety of animals with a variety of vectors. Therefore another method is proposed. 


\section{HEART OF THE PROBLEM AND METHOD FOR ITS SOLUTION}

Heart of the stated problem is in the following. There is a set of elements to be assessed in terms of the effectiveness of their functioning, and there is a set of criteria for assessment of this effectiveness. An algorithm is needed that connects elements and criteria, and allows determining the optimal variant of this system functioning.

Elements include: land, buildings, technological equipment, transport vehicles, animal stock, and plants. Criteria include: quality, price, reliability, productivity and effectiveness.

The solution of such problem is impossible with neither methods of regression analysis due to the impossibility to obtain a countable set of experimental data, nor methods of mathematical programming due to the impossibility to obtain a functionally related set of needed data. In this regard, it is proposed to focus on the mathematical method using ordered sets. Its essence is as follows. The problem is stated. Building an ordered set of elements to be studied and an ordered set of criteria to be used for these researches is carried out. As a result of studies, the algorithm should be created, which allows solving the stated problem. The complexity in this case is that initial sets are, as a rule, represented in the dimensional form (in roubles, hours, calories, etc.) and their reduction to non-dimensional form is problematic. The second complexity is determination of the order (ranking) of elements and criteria.

\section{EXAMPLE CHARACTERISTIC FOR THIS PROBLEM}

Let us considet the example for a grant receipt by the program «Beginning farmer» for setting-up of family livestock farms. So, the problem: there are 2 livestock MFE: $A^{*}$ and B*, it is required to develop an algorithm to justify the allocation to one of them a cash grant. Buildings and transport vehicles in both farmers are of the same level. Number of cattle stock in farmer $\mathrm{A}^{*}$ - 200 animal units (including of the best fleshing - 100 units), in farmer B* - 300 animal units (including of the best fleshing - 50 units). Number of sheep in farmer $A^{*}-1,000$ animal units (including of the best fleshing - 100 units), in farmer $B^{*}-500$ animal units (including of the best fleshing - 150 units). Whom to give priority to?

Set of elements: cattle stock, sheep; set of criteria: age, fleshing.

By the age the cattle meat is divided into beef of adult cattle (over 3 years) and veal (from 14 days to 3 years). Beef has juicy red colour and pleasant smell of the fresh meat.Veal has a pink colour and a more soft and delicate flavour than beef. Lamb is divided by the age into the meat of young animals (under one year) and the meat of old animals (over 1 year). Meat of young sheep has a light red colour, delicate texture. Meat of old sheep has brick-red colour, rough, with a specific smell. 
By fleshing the cattle stock and sheep are divided into three categories: higher, medium and lower than medium.

Age and fleshing are interrelated.

Fleshing of the cattle stock sold for slaughter is estimated according to GOST R 54315-2011 "Cattle stock for slaughter. Beef and veal in carcasses, halves of carcasses and quarters. Technical specifications". Depending on the age and sex, the cattle stock is divided into 4 groups: I group — adult cattle stock (3 years and older), II group - young does, 1-fold calved down, III group - growing stock (from 8 months up to 3 years), IV group — calf (from 3 up to 8 months), and fleshing - into the first and second categories.

Fleshing of sheep sold for slaughter is estimated according to GOST R 31777-2012 "Sheep and goats for slaughter. Depending on the age, sheep are divided into adult sheep (over 12 months), young sheep (4 to 12 months) and lambs (from 14 days to 4 months), and fleshing into the first and second categories.

Allocation of all cattle in 4 levels is considered reasonable enough: the cattle stock of I and II groups of the best fleshing in the 1st level, the cattle stock of III and IV of the best fleshing in the 2nd level, the cattle stock of I and II groups of the average fleshing in the 3rd level, the cattle stock of III and IV groups of the average fleshing in the 4th level, and sheep into 2 levels: 1 st - best and 2nd average.

In this case to simplify calculations, additional assumptions were made and all the cattle stocks distributed in 2 levels: the cattle stock of I, II, III and IV groups of the best fleshing in the 1st level, the cattle stock of I, II, III and IV groups of the average fleshing in the 2nd level, and sheep by fleshing into 2 levels: 1 st - best and 2 nd average.

\section{SOLUTION}

Let us unify the task. There are 2 livestock MFE: * $^{*}$ and $\mathrm{B}^{*}$. Buildings and transport vehicles in both farmers are of the same level, therefore, they can be not taken into account in constructing the algorithm for obtaining the comparative effectiveness of MFE. Animals in both farmers are local. Therefore they can be compared only by fleshing (taking into account the age). So: number of cattle stock $-\mathrm{A}_{1}$ - in farmer $\mathrm{A}^{*}$ - 200 animal units (including of the best fleshing $-\mathrm{A}_{11}-100$ units), in farmer $\mathrm{B}^{*}-\mathrm{A}_{2}-300$ animal units (including of the best fleshing $-A_{21}-50$ units). Number of sheep in farmer $A^{*}-B_{1}-1,000$ animal units (including of the best fleshing $-\mathrm{B}_{11}-100$ units), in farmer $\mathrm{B}^{*}-\mathrm{B}_{2}-500$ animal units (including of the best fleshing $-\mathrm{B}_{21}-150$ units). Whom give priority to when allocation of the grant? 
The first step should be the action which settles elements in order. Elements: cattle stock, sheep.

The first step should be the action which settles criteria in order. Criteria: best fleshing, average fleshing.

The third step is construction of a graph of ordered elements, taking into account the ordering of criteria (Fig. 1).

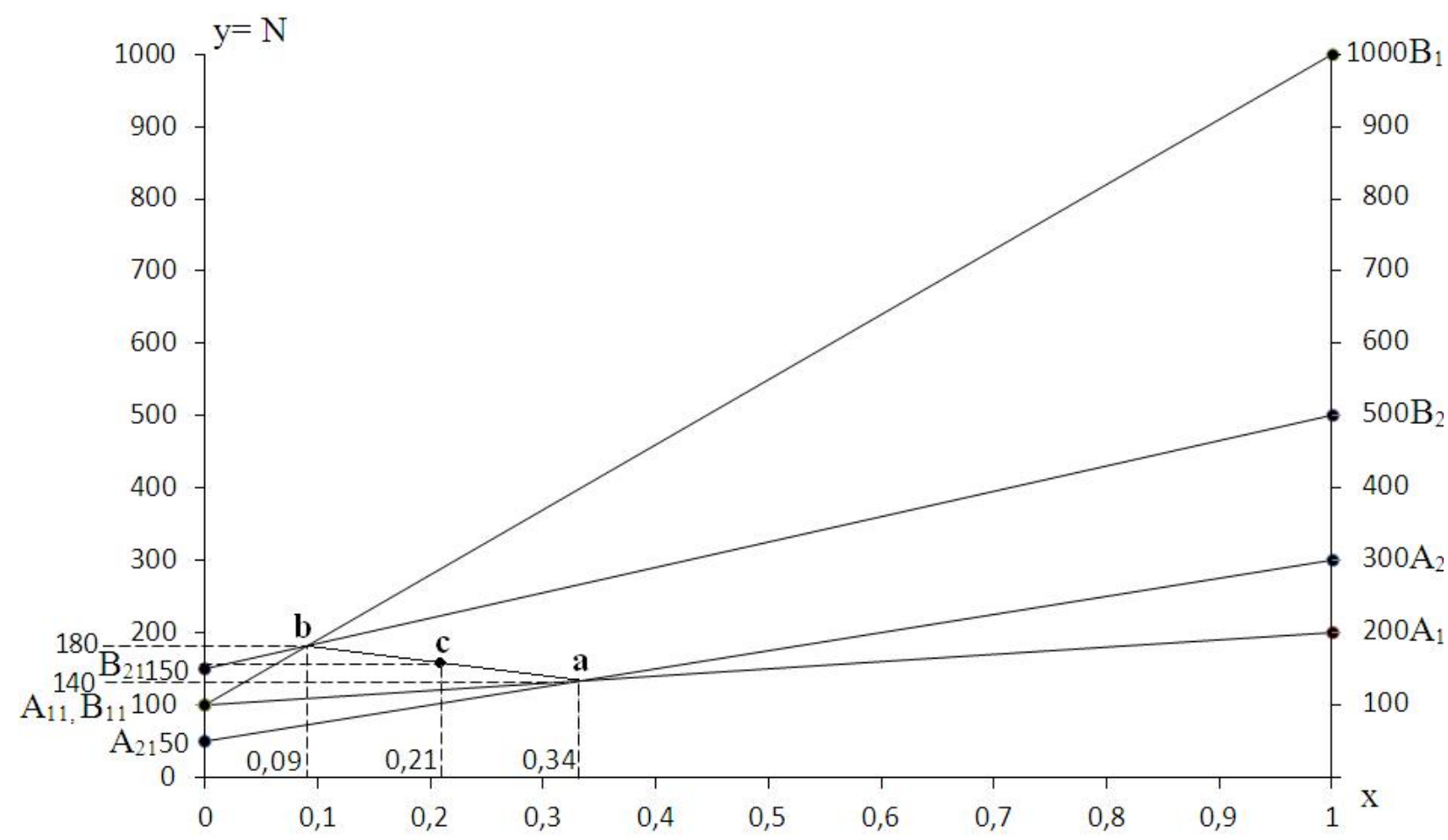

Fig.1. Ordering of elements.

Let us arrange points $11,21, \quad 11, \quad 21$ on the vertical axis $(\mathrm{x}=0)$, and points $1, \quad 2, \quad 1, \quad 2$ on the vertical $(\mathrm{x}=1)$. Let us connect with straight lines points $\quad 11$ and $\quad 1$ and points $\quad 21$ and 2, correspondingly. The intersection point of these lines is . Let us connect with straight lines points $\quad 11$ and $\quad 1$ and points $\quad 21$ and 2 , correspondingly. The intersection point of these lines is $\mathbf{b}$. Middle point of the segment $\mathbf{a b}$ - is the point $\mathbf{c}$. Coordinates of point $\mathbf{a}(0.34$; $140)$, point $\mathbf{b}(0.09 ; 180)$ and point $\mathbf{c}$ - the middle point of the segment $\mathbf{a b}-(0.21 ; 150)$.

Let us note that now the average weight of a calf is considered to be $200 \mathrm{~kg}$, a cow $-400 \mathrm{~kg}$, a bull - $600 \mathrm{~kg}$, the average price of a calf - 90 roubles $/ \mathrm{kg}$, a cow and a bull - 100 roubles $/ \mathrm{kg}$, the average price of 1 cattle unit - 50,000 roubles/pc., the average weight of a lamb - $20 \mathrm{~kg}$, a sheep - $45 \mathrm{~kg}$, the average price of a sheep - 120 roubles $/ \mathrm{kg}$, the average price of an animal unit $-5,400$ roubles/pc. 
Let us continue the graph analysis (Fig. 1). The intersection point $\mathbf{b}$ (sheep, $y=180$ ) exceeds by the absolute value the intersection point a (cattle stock, $y=140$ ). Thus, the numerical superiority of sheep over cattle stock: $\alpha=\frac{180}{140}=1,3$. But the average price of one cattle stock individual exceeds the average price of a sheep: $\rho=\frac{50000}{5400}=9,26$. Coordinates of point c along ordinate $(y=150)$ express the degree of superiority of one factor over the other, and along abscissa $(x=0.21)$ - a shift in the ratio of these factors. So, index $\gamma=y=150$, shift index $\beta=x=0,21$. Let us take into account the scale of graphic constructions. On the $y$-axis, 1,000 animal units conditionally correlated with 20 graph points. Thus, 50 animal units account for 1 graph point. Therefore, the scale: $\sigma=50$. Accounting for listed factors is put in coefficients $\theta$ and $\delta$. Coefficient $\theta$ sets the correlation by the cattle stock, and the coefficient $\delta$ - by sheep.

In respect of the cattle stock: the ratio of cattle stock and sheep of the highest and average fleshing by the both MFE is laid in the coefficient

$\theta=\frac{1}{2} * \frac{A_{11}}{A_{21}} * \frac{B_{2}}{B_{1}} * \frac{B_{11}}{D_{21}}=\frac{200}{300} * \frac{100}{50} * \frac{500}{1000} * \frac{150}{100}=1$.

In respect of sheep: index of the price ratio $(\rho=9.26)$, as well as the shift $(\beta=0.21)$ and the scale $(\sigma=50)$ having a correction value, are in the inverse manner correlated with the superiority of factors by the absolute value $(\alpha=1.3)$ and the degree of superiority of one factor over another $(\gamma=150)$. Therefore coefficient $\delta$ has the form:

$\delta=\frac{\beta * \sigma * \rho}{\gamma * \alpha}=\frac{9.26 * 0.21 * 50}{150 * 1.3}=0.499 \approx 0.5$.

Let us assess the effectiveness of MFE A* by the index

$$
W_{1}=\theta \frac{A_{11}}{A_{1}}+\delta \frac{B_{11}}{B_{1}}=1 \frac{100}{200}+0.5 \frac{100}{1000}=0.51,
$$

and the effectiveness of MFE B* by the index

$$
W_{2}=\theta \frac{A_{21}}{A_{2}}+\delta \frac{B_{21}}{B_{2}}=1 \frac{50}{300}+0.5 \frac{150}{500}=0.32
$$

$\mathrm{W}_{1}=0.51>\mathrm{W}_{2}=0.32$, therefore the priority is given to MFE A*.

In the case when MFE amount exceeds 2, the comparisons is assessed in pairs, and then as a single set. For example, in a case of three MFE $A^{*}, B^{*}$ and $C^{*}, 3$ cases are possible: $\left(\mathrm{W}_{1}>\right.$ $W_{2}>W_{3}$ priority of $\left.\mathrm{A}^{*}\right),\left(\mathrm{W}_{1}>W_{2} u W_{1}>W_{3}\right.$ priority of $\left.\mathrm{A}^{*}\right),\left(\mathrm{W}_{1}<W_{2}, W_{1}<W_{3} u W_{2}<\right.$ $W_{3}$ priority of $\left.{ }^{*}\right)$. 
Problem is complicated when the number of elements exceeds 2 indices, for example 3: cattle stock, -sheep and -hens. In this case it is necessary to abstract cases AB, AC and BC and then analyse them as a single set.

Removal of restrictions and increase in the number of elements (for example, adult cattle stock, young does, growing stock, calves) also complicate the calculation. In this case, researches by elements should be additionally carried out.

Studies of authors [6,7] are also devoted to the application of mathematical methods and mathematical modelling in the agricultural sector.

\section{SUMMARY}

Based on the above it is possible to make a conclusion that the use of the method of restructuring ordered sets provided an opportunity to determine the algorithm which allows replacing expert method of allocating cash grants to enhance the operation effectiveness of competing farm enterprises for the natural-scientific method (independent on the expert opinion).

\section{DISCUSSIONS}

The authors' works $[16,17]$ are also devoted to the application of mathematical methods and mathematical modelling in the agrarian sphere. The authors do not know how to solve problems like those which were described in this article using analytical method. Nevertheless, there are other approaches. For example, it is known that beef cattle breeding resources classification is one of the main methodological tasks along with the development of conceptual approaches to the efficient use of the resources [18]. This allows increasing cattle breeding efficiency. Some issues of increasing the efficiency of cattle breeding as a whole are considered in [19-24]. Sheep breeding efficiency issues are considered in [25-27]. Cattle breeding efficiency issues were considered in [28,29], including the ones using accounting [30]. The economic and mathematical component of agricultural development efficiency as a whole was considered in [31-33]. The above methods of increasing the efficiency of agriculture meet the solution of the problem under consideration, but they are not represented in the form of a mathematical algorithm that gives an unambiguous quantitative answer to the solution of the problem posed. The algorithm mentioned in this article gives such an answer. That is its relevance and scientific nature. 


\section{CONCLUSION}

The proposed method makes it possible to answer not only the question: who is assigned priority to in the allocation of cash grants, but also to give a quantitative characteristic of this conclusion.

\section{CONFLICT OF INTEREST}

Authors confirm that presented data do not contain any conflict of interest.

\section{RECOMMENDATIONS}

The proposed method allows answering not only the question of monetary grants allocation priority, but also quantifying this conclusion. In this regard, it can be recommended to the agencies involved in the allocation of investments to stimulate peasant farms development.

\section{THANKS}

The work was prepared with the support of the Ministry of Agriculture of the Saratov region.

\section{REFERENCES}

[1] Malozemov S. I. Experience of state support of agriculture abroad. Science and contemporaneity. Edition No. 32-1 / 2014, p. 137-141.

Scientific Library KiberLeninka: http://cyberleninka.ru/article/n/opyt-gosudarstvennoypodderzhki-selskogo-hozyaystva-za-rubezhom\#ixzz4ZQG35gxE

[2] Experience of state regulation and support of agriculture abroad. $4^{\text {th }}$ February 2013 sibroy | Category: Agriculture Abroad |

http: // единоличник.pф/stati/selskoe-hozjaistvo-za-rubezhom/opyt-gosudarstvenogoregulirovanija-i-poderzhki-selskogo-hozjaistva-za-rubezhom.html

[3] https://geographyofrussia.com/tipy-dinamiki-chislennosti-naseleniya/

[4] http://waytop.ru/subsidii_fermeram.html

[5] Stukova I.V. Socio-economic aspects of modern agrarian paradigm // Modern problems of science and education - 2012. No. 3.; URL: http://www.scienceeducation.ru/ru/article/view?id=6344. (Date of application: 08/01/2016).

[6] Ivanova N.V. Strategy of the agrarian sector development as a factor of the economic growth in the region (Saratov region). Abstract of dissertation for the degree of $\mathrm{PhD}$ in economics. Speciality 08.00.05 - "Economics and management of the national economy" (specialization - regional economy). Moscow - 2007. 
[7] Podobay N. V. Foreign experience of farms functioning. Herald of Bryansk State Agricultural Academy. Edition No. 3 (2015) / 2015.

[8] Voronin B. A., Voronina Ya. V. State and development tendencies of farms in other countries. Agrarian herald of the Urals. Edition No. 10 (140) / 2015

[9] Bulletin of the Supreme Council of the Republic of Belarus 1991. No. 12. Art. 125.

[10] Bulletin of the Verkhovna Rada of Ukraine. 2003. No. 45. P. 363.

[11] URL: http://online.zakon.kz/Document.

[12] Uzbekiston ovozi. 1992. Aug. 14

[13] Bitutskikh V.G. Value formula. Assessment of the cost of companies. - Kiev, Prom.UA, 2016. - $216 \mathrm{p}$.

[14] Azgaldov G.G. Theory and practice of assessing the quality of commodities (basics of qualimetry). $-\quad \therefore$ Economics, 1982. $-256 \mathrm{p}$.

[15] Rozen, V. V. Ordered vector spaces and their applications / V. V. Rozen. - Saratov: Publ. house of Saratov University, 2014. - 216 p.

[16] Berdnova E.V., Korsunov V.P. Computer modelling on the biological material of living organisms. / Bulletin of the Saratov State Agrarian University named after N.I. Vavilov, No. 7, 2014, pp. 25-27.

[17] Larionov S.V., Korsunov V.P., Berdnova E.V. Competence approach to the preparation of professionals of agrarian specialities of higher qualification. Saratov, Publ. house of Saratov University, 2015. - 103 p.

[18] Vaitsekhovskaya S. S. Resource-saving technologies as a basis for increasing the efficiency of beef cattle breeding // Molodoy Uchyonyy. - 2013. - No. 7. - P. 148-153.

[19] Agricultural enterprise cattle-breeding industry efficiency improvement activity. The case of "Betyun" (Yakutia) http://allbest.ru/o3c0a65635a3ad78a4c53a88421206d37.html

[20] Bogdanov T. A. "Livestock feeding” M., Kolos 2006. - p.432

\section{How to cite this article:}

Molchanov A V, Korsunov V P, Berdnova E V. Mathematical modelling of a farm enterprise value on the agricultural market with the method of restructuring ordered sets. J. Fundam. Appl. Sci., 2017, 9(1S), 889-898. 